Studia Slavica Savariensia 2016. 1-2. 397-404

DOI: $10.17668 /$ SSS.2016.1-2.397

\author{
Тюнде Сабо \\ (Сомбатхей, Венгрия)
}

\title{
ДВОЙНАЯ ДИНАМИКА СЮЖЕТА В ПРОИЗВЕДЕНИЯХ Л. УЛИЦКОЙ «ВЕСЕЛЫЕ ПОХОРОНЫ» И «ИСКРЕННЕ ВАШ ШУРИК»
}

\begin{abstract}
This study examines the manifestation of the dual (linear and cyclical) plot structure as described by Y. Lotman in two of Ulitskaya's works. Besides the thematic similarities, the shared cyclical plot line constitutes the most significant connection between the two works. This analysis will show that the cyclical plot lines of The Funeral Party and Sincerely Yours, Shurik are not connected to an ancient mythical model, as Lotman suggested, but rather the characteristic plot line of the late Middle Ages, the danse macabre, and so instead of the semantics of the eternal cycle of death and resurrection, that of the absolute end is activated in the text.
\end{abstract}

Keywords: Ulitskaya, Alik, Shurik, linear plot line, cyclical plot line, danse macabre

В одной из своих работ Ю. Лотман писал о том, что «современный сюжетный текст - плод взаимодействия и интерференции двух исконных в типологическом отношении типов текстов» - линейного и циклического (ЛОТМАН 1992: 226). А в другом месте ученый утверждал, что в сюжетном пространстве русского романа XIX века преобладает второй, восходящий к мифологическому мышлению тип - циклический (ЛОТМАН 1988).

В последующем мне хочется продемонстрировать описанную Лотманом двойную динамику и также особенность циклической организации сюжета в двух произведениях Л. Улицкой «Веселые похороны» и «Искренне ваш Шурик».

Выбор именно этих произведений не случаен: они довольно близки в тематическом плане, поскольку в обоих ставится вопрос о сущности любви и смерти. В центре обоих сюжетов стоят молодые люди - Алик и Шурик, окруженные женщинами. Оба они женолюбы, и в их отношениях к женщинам эротическая, телесная любовь тесно взаимосвязана со смертью. В сюжетах явно обнаруживается двойная динамика, описанная Лотманом. Но циклическая организация сюжета восходит не к исконно мифологическому мышлению, как предполагал Лотман в своей теории, а 
к распространенному в средневековой Европе жанру «пляски смерти», что придает особый смысл циклической организации текстов.

Повесть «Веселые похороны» вышла в свет в 1997-ом году. Действие происходит в среде русских эмигрантов в Нью-Йорке, которых связывает нечто «неотменимо общее: пересеченная граница, пересеченная, запнувшая линия жизни, обрыв старых корней и выращивание новых...» (УЛИЦКАЯ 2013: 133). Главной метафорой этого неопределенного состояния является смерть художника Алика. Процесс умирания является центральным событием сюжета и, с одной стороны, изображается как абсолютный конец, а, с другой стороны, как переворот, переход из одной сферы в другую. Двойственный характер смерти Алика ярче всего показан в восприятии его жены Нинки. «Со дня смерти Алика она понимала только две вещи: что он выздоровел и что его больше нет. Эти вещи не совместились бы в обычном человеческом сознании» (УЛИЦКАЯ 2013: 196). Они, однако, отлично совмещаются в сюжете, который определяется именно этим двойственным восприятием смерти.

Факт смерти человека - как об этом также писал Ю. Лотман - придает доминантную роль началу и концу художественного произведения (ЛОТМАН 1993). В повести Улицкой начало и конец маркируется самим Аликом, который пользуется нецензурным выражением «пиздец», обозначающим, в числе прочих коннотаций: «провал, конец, смерть». В начале сюжета слово появляется на майке дочери, как сделанная героем декорация, а в конце сюжета как последнее слово Алика, которым он обращается к друзьям на поминках. С помощью повтора этого слова замыкаются начало и конец сюжета и создается кольцевая структура, в центре которой - умирающий герой.

Такая структура лежит в основе всех населенных многочисленными персонажами сцен повести ${ }^{1}$. Алик всегда находится в центре: «[его] посадили в кресло, обложив со всех сторон подушками. Это было всегдашнее его место, и все медленно вращались по квартире...» (УЛИЦКАЯ 2013: 65). Однако, этот центр характеризуется все нарастающей пустотой, отсутствием чего-либо. С одной стороны, на физиологическом уровне герой постепенно лишается способности ощущать окружающий мир. Сначала наступает мышечное дистрофия, потом он теряет вкус еды, потом пропадает зрение и голос. С другой стороны, происходят определенные изменения и на психическом и на метафизическом уровнях. Ирина упрекает его в отсутствии положительных, с точки зрения деловой жизни, качеств, в беспечности и безответственности, и ставит под сомнение его способность любить.

1 См. еще: «Судьба Алика, изломанная линия его жизни выстраивает все повествование по принципу концентрических кругов, то бесконечно расширяясь в прошлое, в глубины памяти, то снова стягиваясь к «точке умирания», к моменту настоящего» (ПОЛУПАНОВА 2013). 
Встреча со священником и раввином подчеркивает в образе Алика отсутствие связи с метафизическим миром. Во время беседы с отцом Виктором Алик остро ощущает «отсутствие присутствия Третьего» (УЛИЦКАЯ 2013: 73), а Реб Менаше определяет героя как «плененного ребенка», который лишен Торы и поэтому живет оторванным «от той жизненной основы, которую он [раввин] признавал исключительно за Торой» (УЛИЦКАЯ 2013: 91).

Кольцевая структура ярче всего проявляется в сцене с латиноамериканскими музыкантами. Они входят в мастерскую как раз в начале агонии Алика, на них висят «скелетики», их инструменты - черепа и маленькие косточки. Они выстраиваются гуськом, двигаются по кругу, и их древняя музыка - как догадывается Алик - представляет собой пляску смерти, смысл которой - «буквальный рассказ об умирании тела... В ней присутствовал стук сердца, дыхание легких, движение воды и даже ворчащие звуки пищеварения» (УЛИЦКАЯ 2013: 154). Все это вполне совпадает с наблюдением Анны Леонавичус, которая в анализе стихотворения А. Блока «Как тяжело мертвецу среди людей», пишет следующее: «В свою очередь, мотив пляски смерти как бы отождествляет все бытие человека с жизнью его тела, смерть ассоциируется с потерей тела, всей сферы чувств и человеческой индивидуальности. Логика мотива тем самым предполагает отсутствие или недостаточность духовного бытия, как будто в земной жизни изображенных персонажей не существует духовное, невещественное измерение» (ЛЕОНАВИЧУС 2015: 86). Кроме основной роли тела, Й. Хейзинга, в своей книге «Осень средневековья» подчеркивает эротический элемент в связи с женскими образами в сюжете «пляска смерти» (ХЕЙЗИНГА 1988). В повести Улицкой эротика явно присутствует в общении с Аликом полуобнаженных женщин. Например, Валентина «положила палец ему между сухих губ... Похоже, это была последняя ночь их любви... Он сказал очень тихо: - Умру прелюбодеем...» (УЛИЦКАЯ 2013: 112).

«Пляска смерти» - это распространенный в средневековой Европе сюжет, прежде всего в иконографии, а также в поэзии XIV-XVI вв. В нем выражается представление о неизбежности конца, о равенстве всех перед лицом смерти, независимо от рода, возраста, чина и социального статуса. Смерть в этих произведениях «предстает в образе мумифицированного трупа, жнеца, птицелова, охотника с аркебузой» (РЕУТИН 2003), а в более поздних вариантах как скелетон. «Подобные образы смерти объединяются в самостоятельный мифопоэтический ряд, отдельный от догматики христианства и отчасти дублирующий функции еe персонажей...» (РЕУТИН 2003). В иконологии сюжет часто воплощается в хороводе разного статуса людей со смертью вокруг ямы - отсюда кольцевая структура, которая ассоциируется, как правило, с жанром «пляски смерти». 
Подобная картина вырисовывается на похоронах Алика, где около гроба и заранее вырытой ямы собирается такой пестрый народ, что даже опытный владелец кладбища, Робинс не может определить, к какой национальности и профессии относится его «клиент». Эта картина в принципе повторяет вышеописанную кольцевую структуру в мастерской Алика, где около умирающего героя собираются персонажи самых разных национальностей и профессий. На основе всего этого можно сказать, что в сюжете повести «Веселые похороны» активно присутствует визуальный код сюжета средневекового искусства - «пляска смерти» как выражение абсолютного конца.

Линейная динамика сюжета в повести представляется как особое возрождение, как переход из одной сферы в другую. Это - и возрождение Алика в своей дочери, Тишорт; это - и счастливый поворот в судьбах женщин и друзей Алика после его похорон; это - и переворот в истории России, как на это указывают московские события за которыми герои следят по телевизору; это - и смена парадигм в большом историкокультурном временном пространстве. Этот процесс отец Виктор определяет как «созидание нового народа», Алик - как рождение новой культуры. Даже Рев Менаше готов признаться в том, что происходит определенный процесс, который он воспринимает как «большую победу язычников».

Новое состояние человека в процессе смены парадигм в повести выражается, с одной стороны, с помощью кода магического мышления, характерного для первобытных народов и также для маленьких детей. С другой стороны, оно маркируется мощным сюжетом-символом конца средневековья - «Божественной комедией» Данте ${ }^{2}$.

$$
* * *
$$

В романе «Искренне ваш Шурик», вышедшем в 2004-ом году, линейная динамика сюжета проявляется совсем по-другому. Тут мы имеем дело с воспитательным романом, который представляет собой третий тип по системе Бахтина, в котором «становление происходит в биографическом времени, оно проходит через неповторимые, индивидуальные этапы. Оно может быть типичным, но это уже не циклическая типичность. Становление здесь является результатом всей совокупности меняющихся жизненных условий и событий, деятельности и работы. Создается судьба человека, создается вместе с нею и он сам, его характер. Становление

\footnotetext{
2 Тема линейной динамики сюжета в повести Улицкой детально разработана мною в докладе «Театрализация смерти (Л. Улицкая: «Веселые похороны»)», прозвучанном на международной конференции «Взаимодействие литератур в мировом литературном процессе», в городе Гродно в сентябре 2016.
} 
жизни-судьбы сливается со становлением самого человека» (БАХТИН 1979).

Развитие характера героя, формирование его судьбы происходит в Москве в определенную историческую эпоху (1950-1980-ые гг.), от его рождения до тридцатилетнего возраста. В жизни Шурика мало событий, долгие периоды даже не отмечены нарратором. Выделяются только те моменты, которые обозначают новую фазу в «мужской жизни» героя, например, отдельная комната, или вечеринка для одноклассников в последнем учебном году. Главным таким моментом является встреча с первой любовью, Лилей, которая, однако, вскоре покидает героя навсегда. Ее исчезновение тесно связывается со смертью бабушки Шурика. «Отъезд Лили так прочно соединился в его памяти со смертью, что... ему все казалось, что хоронят Лилю» (УЛИЦКАЯ 2010: 73). После этого Шурик практически служит только случайным женщинам, судьбы которых переплетаются с его биографией, а он при этом теряет самого себя. Когда Шурику исполнилось тридцать лет, он, глядя в зеркало «вдруг заметил, что за ним следит из зеркала незнакомый ему мужчина, немолодой, довольно мордастый, с намечающимся вторым подбородком и мятыми подглазьями. Было мгновение какого-то ужасного неузнавания себя...» (УЛИЦКАЯ 2010: 526).

Такой, неудовлетворительный результат линейного развития, становления героя можно объяснить циклической организацией сюжета, главными особенностями которой Ю. Лотман выделил «подчиненность циклическому временному движению», «единство между отдаленными сферами мира» и «тенденцию к безусловному отождествлению различных персонажей» (ЛОТМАН 1992: 225).

В романе Улицкой обнаруживаются все три эти особенности: циклические повторы некоторых событий (например, рождественских спектаклей), изоморфизм внешних сфер, где герой одинаково обслуживает своих женщин и отождествление разных персонажей. Отождествлены в определенном смысле женщины, с которыми имеет дело Шурик, и он сам отождествляется с разными членами семьи и выполняет разные роли в семье. Его имя повторяет имя отца, и также дедушки. Тем не менее, роль отца выполняет бабушка, «мужественная», воспитанная в Европе, Елизавета Иванова. После ее смерти Шурику достается эта же самая роль, и он становится в одном лице мамой и папой своей матери. «Произошла окончательная смена ролей - Вера поставила сына на место своей покойной матери» (УЛИЦКАЯ 2010: 98). В то же время Шурик выполняет и роль мужа, когда нужно, фиктивно, а когда понадобится, - на практике. Девочка из фиктивного брака носит его фамилию, а его родному ребенку от Валерии не суждено появиться на свет. Девочка из фиктивного брака возбуждает в маме Шурика материнское чувство, она «испытала смутно-приятное чувство: как будто 
Мария их с Шуриком дочь» (УЛИЦКАЯ 2010: 458). Эти разные изоморфизмы циклической организации сюжета в итоге приводят к релятивизации мужской роли, и, благодаря этому, линейное развитие героя оказывается неудачным.

Тем не менее, позиция героя среди женщин образует кольцевую структуру, также, как и в повести «Веселые похороны». В кругу женщин центром является Шурик, как дома, так и вне его. «У Шурика выработалось неосознанное чувство, что и само добро есть начало женское, находящееся вовне и окружающее его, стоящего в иентре» (УЛИЦКАЯ 2010: 38) и «ему представлялось, как все они [женщины] его обступают [выделено мною - Т.С.]» (УЛИЦКАЯ 2010: 409).

Однако этот центр, в образе Шурика, также, как и в образе Алика, определяется пустотой - отсутствием отца, смертью бабушки, исчезновением настоящей любви, и, в конце концов, недостатком мужской личности. И, хотя, на первый взгляд, сексуальное обслуживание женщин показывается как позитивная энергия, на самом деле, эта энергия также является компенсацией чего-то. По мере того, как растет количество женщин, становится все более очевидно, что сексуальность Шурика имеет пассивный характер. Инициаторами всегда выступают женщины, а Шурик прежде всего испытывает жалость к ним. «Он давно уже догадался, что это и есть главное чувство мужчины к женщинам жалость» (УЛИЦКАЯ 2010: 203).

В семантическом поле слова «жалость», среди прочего, присутствует и семантика смерти, о чем свидетельствуют этимологические словари ${ }^{3}$. Если принять во внимание эту семантику вместе с кольцевой структурой, то можно сказать, что и в этом произведении Улицкой присутствует сюжет «пляски смерти», в которой персонажи разного пола, возраста и социального статуса окружают хороводом яму, куда их по очереди уносит олицетворенная смерть. С этой точки зрения не удивительно, что судьбы вращающихся около Шурика женщин развиваются неблагополучно: Алю сбивает машина, Валерия и Светлана умирают, Стовба со своей девочкой бесследно исчезает.

Связь образа Шурика со смертью подтверждается и мифологическим прототипом: бог Танатос, олицетворяющий смерть и разрушение в греческой мифологии, тоже родился и рос без отца. Взаимосвязь Танатоса с Эросом в образе Шурика дает основу и для психоаналитической интерпретации героя - но это тема уже другой статьи.

3 Индоевропейский корень * $\mathrm{g}^{\mathrm{w}} \overline{\mathrm{e}} \mathrm{l}-$ содержит семантику «смерть», которая сохранилась в англосаксонском и прусском вариантах слова. Старославянская форма «жаль» имела значение «гробница», тогда как старорусский вариант «жальникъ» обозначал «кладбище». (См. ПРЕОБРАЖЕНСКИЙ 1969: 221 и ЧЕРНЫХ 1993: 291.) 
Если рассмотреть эти два произведения Улицкой в структурном плане, можно заметить, что в них явно присутствует двойная динамика сюжета, взаимодействие линейного и циклического принципов. Однако они выступают не просто как структурные принципы, а имеют определенную функцию и также семантику - благодаря чему создаются совсем разные сюжеты.

Линейная динамика различна в двух произведениях. В повести «Веселые похороны» она проявляется как переход из одного состояния в другое, как на уровне личной жизни героев, так и в большом историкокультурном времени. В романе «Искренне ваш Шурик» линейная динамика определяет сюжет воспитания, становления личности и судьбы главного героя.

То, что роднит эти два произведения Улицкой - это связь циклической организации сюжета не с исконным мифологическим мышлением, а с «пляской смерти», сюжетом-символом конца средневековья. В «пляске смерти» акцентируется неизбежность и окончательность смерти и исчезновение тела, и, таким образом, маркируется не постоянное возрождение, а абсолютный конец - изменяя тем самым изначальный смысл циклической организации рассмотренных текстов.

\section{Литература}

БАХТИН 1979 = БАХТИН М.М. Роман воспитания и его значение в истории реализма (по Гете). Постановка проблемы романа воспитания. http://litprosv.niv.ru/lit-prosv/bahtin-roman-ego-znachenie/postanovka-problemy-romanavospitaniya.htm (Последний доступ: 30. 06. 2016.)

ЛЕОНАВИЧУС 2015 = ЛЕОНАВИЧУС А.В. Бал как пляска смерти у А. Блока и русских романтиков // Вестник РГГУ № 8 (151), М., 2015. 85-99.

ЛОТМАН 1988 = ЛОТМАН Ю. Сюжетное пространство русского романа ХІХ столетия // В школе поэтического слова: Пушкин. Лермонтов. Гоголь. М., Просвещение, 1988. 325-348.

ЛОТМАН 1992 = ЛОТМАН Ю. Происхождение сюжета в типологическом освещении // Статьи по семиотике и топологии культуры. Избранные статьи в трех томах. Т.1. 224-243.

ЛОТМАН 1993 = ЛОТМАН Ю. Смерть как проблема сюжета // Studies in Slavic Literature and Poetics, Vol. XX; Literary Tradition and Practice in Russian Culture, Amsterdam - Atlanta, 1993. http://refdb.ru/look/2143603.html (последний доступ: 03. 06. 2016)

ПОЛУПАНОВА $=$ ПОЛУПАНОВА А.В. Игра и театрализация действительности как принципы организации текстового пространства в повести Л. Е. Улицкой «Веселые похороны» // Филологические науки. Вопросы теории и практики Выпуск № 11-1 (29) / 2013. 158-161. http://cyberleninka.ru/article/n/igra-iteatralizatsiya-deystvitelnosti-kak-printsipy-organizatsii-tekstovogo-prostranstva-vpovesti-l-e-ulitskoy-veselye-pohorony (Последний доступ: 14. 05. 2016.) 
ПРЕОБРАЖЕНСКИЙ $1969=$ ПРЕОБРАЖЕНСКИЙ А.Г. ЭТИМОЛогический словарь русского языка в 2 т. Т. 1. Москва: Гос. изд. иностранных и национальных словарей, 1969.

РЕУТИН 2003 = РЕУТИН М.Ю. Пляска смерти // Словарь средневековой культуры. М., 2003. стр. 360-364. http://www.fedydiary.ru/html/032011/13032011-05a.html (Последний доступ: 17. 07. 2016.)

УЛИЦКАЯ 2010 = УЛИЦКАЯ Л. Искренне ваш Шурик. Москва: Эксмо, 2010.

УЛИЦКАЯ 2013 = УЛИЦКАЯ Л. Веселые похороны. Москва: АСТ, 2013.

$\begin{array}{lllll}\text { ХЕЙЗИНГА } & 1988=\text { ХЕЙЗИНГА Й. Осень }\end{array}$ средневековья. http://lib.ru/FILOSOF/HUIZINGA/osen.txt (Последний доступ: 30. 06. 2016.)

ЧЕРНЫХ $1993=$ ЧЕРНЫХ П.Я. Историко-этимологический словарь современного русского языка в 2 т. Т. 1. Москва: Русский язык, 1993. 